\title{
Viewpoints in the '90s - The first 10 years: A decade in defiance of the odds
}

\author{
Some say they don't know - some have all their [my] dreams come true \\ (Perhaps love by John Denver)
}

ABR THOMSON MD PhD FRCPC FACP FACG, CN Williams MD FRCPC

The Canadian Journal of Gastroenterology is now 10 years old! Our Editors-in-Chief have penned this viewpoint to mark the occasion.

$\mathrm{B}$ b Kalina had heard through the proverbial grapevine that East meets West with a couple of collegial doers. He approached us over a Holiday Inn buffet to consider undertaking a high risk venture to establish a new Canadian medical journal. From his market research, Bob had established that there was the possibility of a niche with the necessary market share of print advertising. We took the proverbial bull by the horns - friends since an exhilarating oom-pah-pah hike through the Falkian Black Forrest - and agreed. Foolhardily for certain, in a land where the half-life of new medical journals is less than three years!

An Editorial Board was the next step. "Many are called but few are chosen." The international folks were really quite receptive when approached to join, but some of our colleagues at home were less so - "what if it fails?" Well, yes, I guess it just fails, but we have no intention for that to happen! "Well, call me again once your new journal is a success." Sure, thanks but no thanks. Your cheque is in the mail. The new immorality, etc....

The challenge to every fledgling editor is soliciting articles. "I'd like to help, you know, but I'm too busy and you're really not very prestigious, you know, after all (you know)." Undeterred, an editorial policy was struck: fair, pro-active and supportive reviews, fast-tracking of summaries and reviews, encouraging young authors (everyone is young when you're an author), a peppering of controversy, and with everything published within six months after acceptance. A high standard was established, much to the embarrassment of one Editor-in-Chief who enjoys the dubious pleasure of being the first contributor to have an article rejected!

Initially the relationship with the Canadian Association of Gastroenterology (CAG) was best described as pleasant but strained. A series of rather courteous $C A G$ presidents did not wish the Journal to become the official journal of the Association. This was in part because Clinical Investigative Medicine was technically, but never officially, the CAG journal. But Clinical Investigative Medicine, being a multidisciplinary journal, was not focused on gastroenterology, and in it were no case reports or material of a psychosocioeconomic or controversial nature. Rejected and rebuked, we carried on. Distribution grew to over 15,000 , and the number of issues expanded to eight/year, plus supplements arising from important international meetings. In recognition of the impact of the Journal, it was indexed by Current Contents, Scisearch, Research Alert, Excerpta Medica (Embase) and Ad Referendum, and is now on the Internet in abstract form. Letters of appreciation and support continued to trickle and then flow to the Editors-in-Chief.

Janet O'Flaherty was appointed Managing Editor early in the life of the Joumal, and the Editors-in-Chief and members of the Board have always enjoyed a happy, collegial, constructive and enthusiastic relationship with the publisher, Bob Kalina. Janet has just left for greener pastures (Ode to an English Garden). We wish her much happiness and every success. Bob was the entrepreneur who took the financial risk, and thankfully his energy and enthusiasm paid off; Pulsus expanded and now publishes several medical journals. We are proud to be one of the original successes.

Ivan Beck helped encourage the CAG to get back on track with thoughts about the medical community needing a gastroenterology journal for the clinical practitioner, as well as the research scientist. In one particularly melting ex- 
change at a CAG executive meeting, 'ITB' cut to the bone and crystallized the discussion: "outside Canada, The Canadian Joumal of Gastroenterology is the CAG journal. The Canadian Joumal of Gastroenterology is widely read, is quoted, is successful, and is going to survive. The Canadian Journal of Gastroenterology speaks for Canadian gastroenterology. Isn't it about time we made the relationship 'official'?" Further discussions with a series of three CAG presidents finally brought success and we became official - much like a common-law relationship becoming sanctified after years of cohabiting. Now negotiations are proceeding with the Canadian Association for the Study of the Liver (CASL), and we hope to speak - or write - for them soon as well.

As Editors-in-Chief we have had our highs and lows. The highs have come from marvellous and productive contributors like Jim Barrowman, Hugh Freeman and Noel Hershfield. The lows have come from the unpleasantness of dealing with the issues of fraud. One instance was receiving three manuscripts, all large clinical studies, from a single centre and author on different subjects! When polite inquiries were made trying to substantiate the validity of the studies, and even the author's medical qualifications, the author disappeared from the face of the earth, with a forwarding address in St Elsewhere, North Overshoe. Another awkward instance arose from submission of an alleged consensus document, in which not all of the named participants actually took part, and of whom only a handful actually read the paper, let alone had enough to do with it to warrant authorship. As a result of instances such as these, our policies have developed, responded, matured and flourished. Even when advertisers suddenly withdraw their advertising because of perceived slights, we keep a stiff upper lip, take a firm but conciliating tone, and keep on trucking.
And quo vadis? A limited number of complimentary copies (150 to different countries) of the Journal go to Central and South America, eastern Europe and the former Soviet Republic using an education grant from a pharmaceutical company, and to former Fellows and colleagues - with very much expressed appreciation. The quality of submissions improves, the number is on the rise; in time the thickness of each issue will grow and the number of annual issues will strive to reach a baker's dozen.

And the citation impact? Interestingly, in a recently commissioned study, the impact of the Journal on Canadian gastroenterologists was really quite impressive (who was more surprised - pleasantly of course - than the Editors-in-Chief?!). Apparently Canadian gastroenterologists view the Jourmal as having more impact than the New England Journal of Medicine - unbelievable! We are 'on the Net', we publish the abstracts and program for the recently instituted Canadian Digestive Diseases Week and we would be happy to receive your pet project, your written pride and joy, your next paper!

We look forward to the next 10 years, whereupon we may look back and say with some quiet and modest satisfaction that perhaps we helped to make a difference. And to our many cooperative, cheerful and helpful reviewers: our hats are off to you, with many thanks. To those of you who can't be bothered to help review or submit papers: too bad; have a nice life. To our Editorial Board and advertisers: three cheers! To our publisher: thank you for giving us the chance and pleasure of being able to work with you.

And to our spouses, Beryl and Jeannette, and families, thank you for understanding that creative juices must flow, we need to reach for the stars and we still have "miles to go before we sleep" (Stopping by the Woods on a Snowy Evening by Robert Frost). 


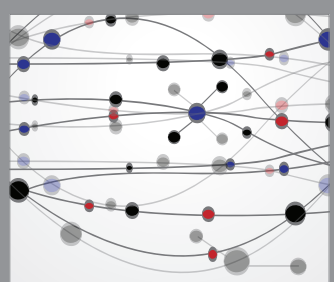

The Scientific World Journal
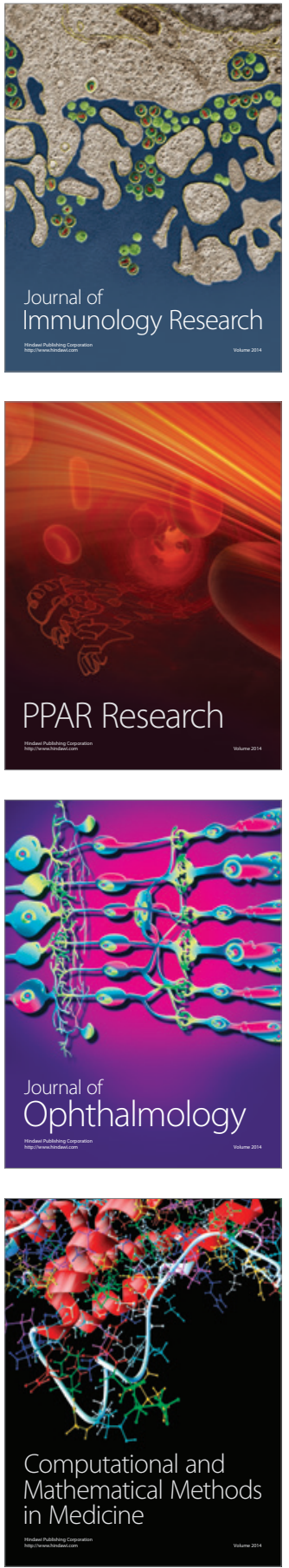

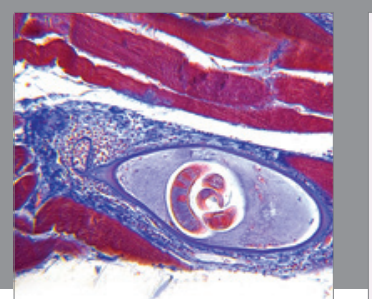

Gastroenterology Research and Practice

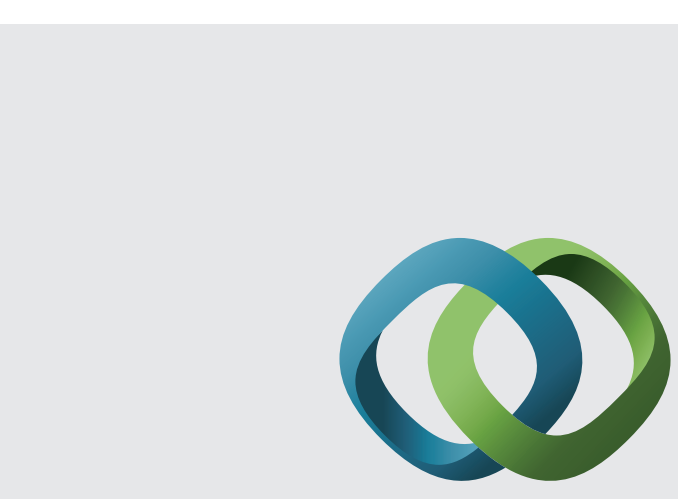

\section{Hindawi}

Submit your manuscripts at

http://www.hindawi.com
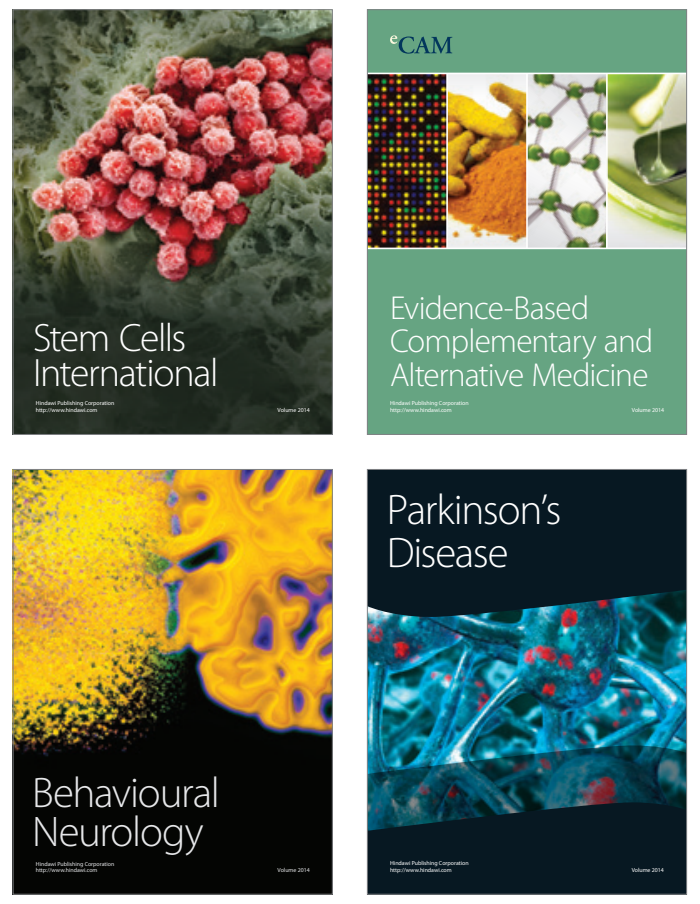
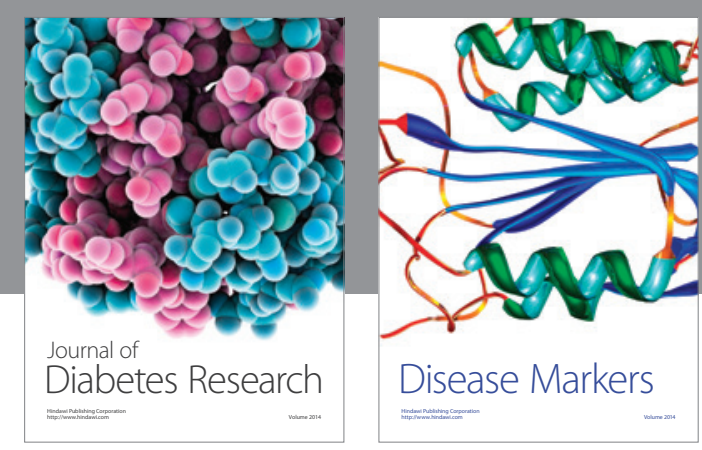

Disease Markers
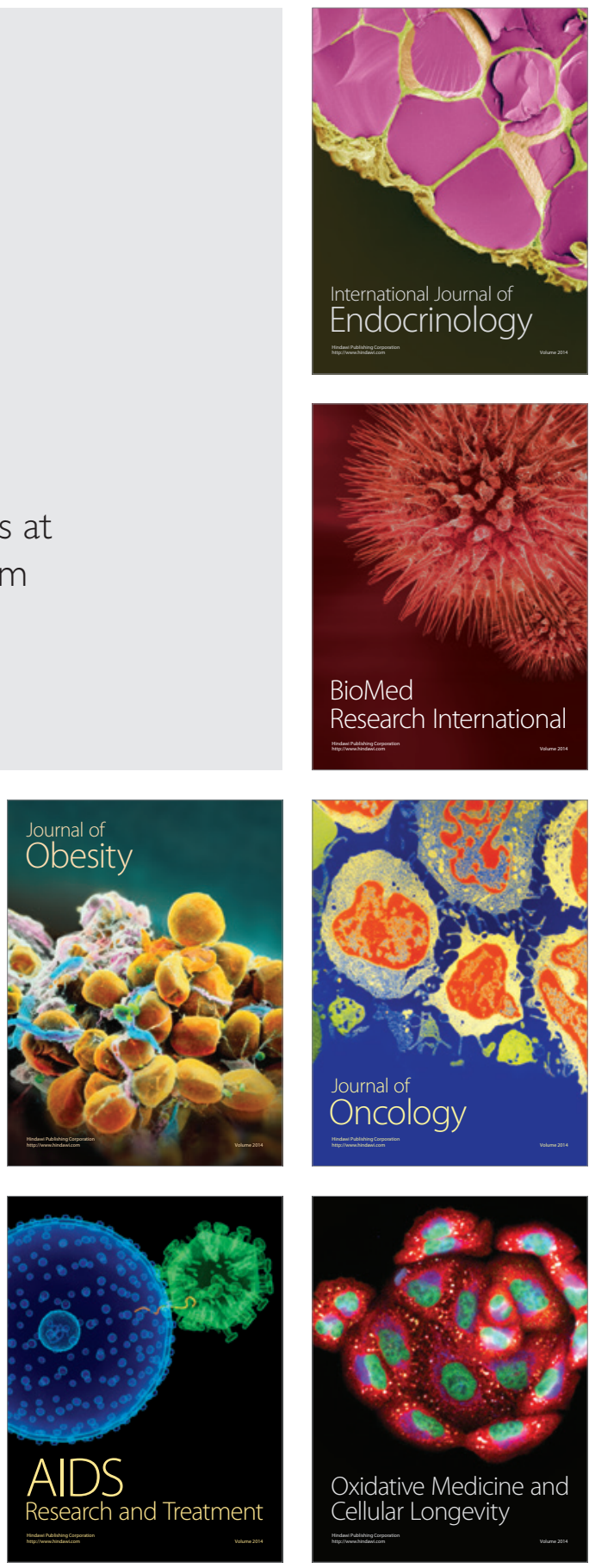